\title{
INFLUENCE OF PLASMA JET TEMPERATURE ON THE SYNTHESIS AND STRUCTURE OF YSZ COATINGS *
}

\author{
Ž. Kavaliauskas, K. Brinkienè, J. Čèsnienè, and R. Kèželis \\ Lithuanian Energy Institute, Breslaujos 3, LT-44403 Kaunas, Lithuania \\ E-mail: zydrunas@mail.lei.lt
}

Received 26 September 2008; revised 2 February 2009; accepted 19 March 2009

\begin{abstract}
The paper describes a process for preparation of yttria stabilized zirconia (YSZ) coatings by plasma spray technique employing non-equilibrium plasma spray technology at atmospheric pressure. Yttria-stabilized zirconia (10-15 wt. \% $\left.\mathrm{Y}_{2} \mathrm{O}_{3}\right)$ powders (10-105 $\mu \mathrm{m}$ in diameter) have been used. Plasma sprayed coatings have been characterized using scanning electron microscope (SEM) and X-ray diffractometer (XRD) for the microstructural study and phase analysis as a part of a process optimisation study. The dependence of microstructure of coatings on initial powder characteristics and the influence of deposition temperature in the range of $3000-3350^{\circ} \mathrm{C}$ on the structural characteristics of plasma sprayed coatings were investigated. By the data of XRD analysis, all samples were obtained with cubic crystal orientation. It has been found that crystallite size has tendency to decrease with increasing the deposition temperature. YSZ deposited at $3150-3350{ }^{\circ} \mathrm{C}$ are found to have a nanocrystalline structure with average crystallite size of $75 \mathrm{~nm}$. The samples sprayed using coarse-grained powder feed are characterized by larger grain size and crystallite size. The main parameters influencing the coating formation are the properties of the initial powder and the plasma process temperature. The SEM analysis showed that the best temperature region for the deposition of YSZ coatings was about $3200-3350{ }^{\circ} \mathrm{C}$.
\end{abstract}

Keywords: coatings, plasma spraying, microstructure-final, $\mathrm{XRD}, \mathrm{ZrO}_{2}$

PACS: 52.77.Bn, 68.55.J-, 68.90.+g

\section{Introduction}

High temperature oxide ceramics based on zirconia are widely used due to their excellent properties [1-3]. Zirconia-based ceramics fabricated using different processing techniques are successfully used as a structural or a functional ceramic material $[4,5]$. In recent years a great attention is focussed on the thin coatings of ionically conducting materials $[6,7]$.

Advanced electronics and up-to-date branches of industry need advanced methods for ceramic processing in these applications. The required properties of ceramic materials can be optimised by the processing method and its tuned parameters, because of the strong dependence between processing, microstructure, and properties. The powder-based processing requires multi-step operations with high temperature sintering process to provide the final properties and dimensions of the final product. These steps are long-lasting and require a great deal of time to complete.

\footnotetext{
* Results presented at the international conference Radiation Interaction with Material and Its Use in Technologies 2008, 24-27 September 2008, Kaunas, Lithuania
}

Plasma spraying can be used as an economic alternative method for the deposition of ceramic coatings on various substrates [2,5-7]. Good mechanical and physical properties of plasma sprayed coatings are determined by their microstructure [8]. The microstructure of plasma sprayed coatings is determined both by processing parameters and morphology of initial powder [9]. A lot of plasma processing variables determine the microstructure and properties of deposited coatings. Process gases, flow rates, voltage and amperage, spray distance, locations of powder injection influence the melting state of initial powder in the plasma jet and, as a result, the properties of obtained coatings.

Therefore, an attempt to obtain dense and homogeneous yttria stabilized zirconia (YSZ) coatings in the temperature range of $3000-3350{ }^{\circ} \mathrm{C}$ was undertaken. In this study, we report the results of the formation and microstructural analysis of plasma sprayed YSZ coatings obtained by non-equilibrium air plasma spraying technology at atmospheric pressure. The objective of this work was to examine how the initial powder particle size and the deposition temperature influence the structural characteristics of plasma sprayed coatings. 


\section{Experiment}

A special test bench with long operation time and stable outlet plasma jet parameters was used for YSZ deposition $[9,10]$. The average outlet jet temperature was estimated from heat balance.

In the present study commercial YSZ powders (CERAC, USA), typically $99 \%$ pure with $10-15$ wt. $\%$ of yttria, were used for the deposition of the coatings. Initial powder with different particle size from 10 to $105 \mu \mathrm{m}$ in diameter, further denoted as Z1 with particle size of 10 $44 \mu \mathrm{m}$ and $\mathrm{Z} 2$ of $44-105 \mu \mathrm{m}$, were utilized for plasma spraying.

Polished stainless steel sheets were used as the substrate material. Prior to plasma spray, the substrate surfaces were hand-polished to $0.05 \mu \mathrm{m}$ finishing, cleaned with acetone, and dried in air before they were used. To obtain a uniform coating, the substrates were placed on a cylindrical fixture, which could rotate around its own axis during plasma spray, $20-100 \mathrm{~mm}$ away from the exit of the torch. The thickness of the steel substrates was $100 \mu \mathrm{m}$.

The JEOL JSM 5600 scanning electron microscope (SEM) was employed to examine the microstructure characteristics of plasma sprayed coatings. Microstructural investigations were carried out for sprayed coatings and for powder analysis. The crystal structure of initial powders as well as crystallite size of the plasma deposited coatings were analysed using an X-ray diffraction (XRD) (DRON UM1) with $\mathrm{Cu} \mathrm{K}_{\alpha}$ radiation. The mean crystallite size was estimated from integral width of the diffraction peaks (111) of YSZ by the Crystallographica Search-Match programme [11]. The mean grain size was estimated by linear intercept method using SEM micrographs. The coating thickness was eval-

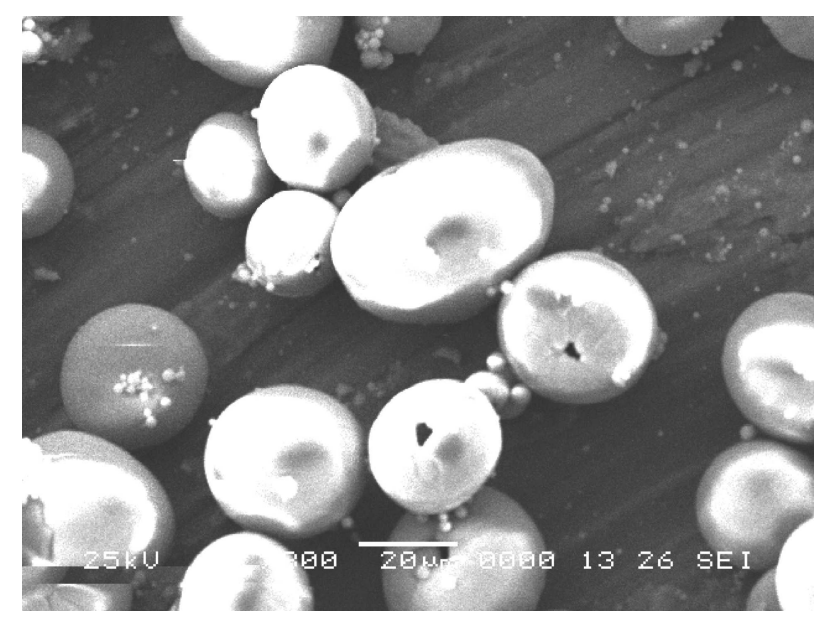

(a)
Table 1. Plasma spraying parameters for YSZ coatings' deposition.

\begin{tabular}{lc}
\hline Amperage of plasma torch, A & $170-220$ \\
Plasma jet temperature, ${ }^{\circ} \mathrm{C}$ & $3000-3400$ \\
Total mass flow of air, $\mathrm{g} \mathrm{s}^{-1}$ & 5.5 \\
Total mass flow of hydrogen, $\mathrm{g} \mathrm{s}^{-1}$ & $0-1.5$ \\
Spray duration, $\mathrm{s}$ & $30-60$ \\
Spray distance, $\mathrm{mm}$ & 70 \\
\hline
\end{tabular}

uated by cross-sectional scanning electron microscopy observation.

\section{Results and discussion}

Seven groups of samples were deposited using plasma spraying from initial Z1 and Z2 powders. The main parameters of plasma process regime for deposition of YSZ coatings are listed in Table 1. Changing plasma gas composition with addition of hydrogen gas, the plasma jet properties were changed.

The crystal structure of powders used is cubic zirconia. After being dried, the initial powders were used for plasma spraying. Characteristics of plasma sprayed coatings versus powder used and the operating parameters of the plasma torch are presented in Table 2. Spray duration is $30-60 \mathrm{~s}$, spray distance $70 \mathrm{~mm}$.

Investigation of the influence of initial powder properties and plasma process parameters on the properties of plasma sprayed coatings was undertaken analysing the morphological properties of as-sprayed powders and deposited coatings. The melting state of initial powders in the plasma jet was examined analysing water-quenched powder sprayed into distilled water. Typical morphology of plasma-melted and sprayed powders is shown in Fig. 1. As shown in micrographs

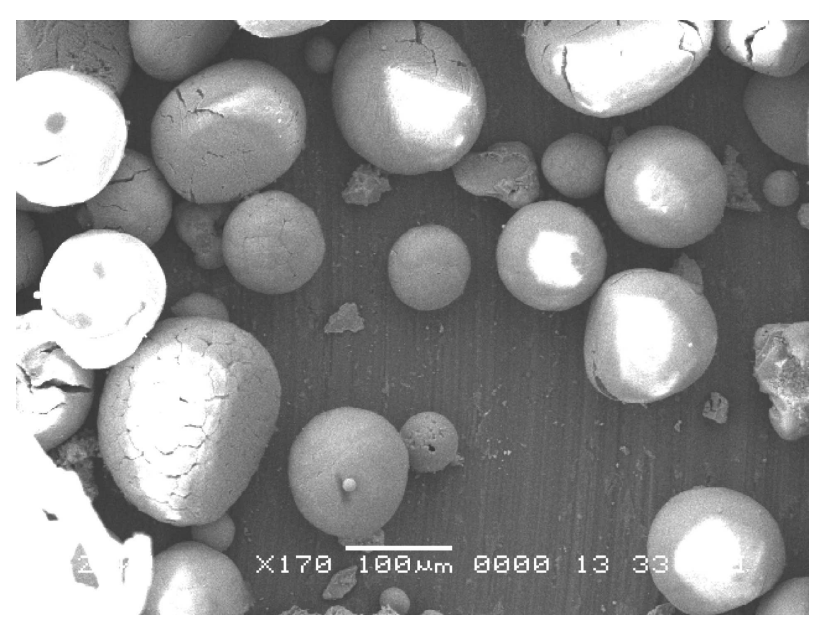

(b)

Fig. 1. SEM micrographs of (a) initial powder Z1 and (b) Z2 after passing through the plasma jet. 
Table 2. Characteristics of YSZ coatings versus initial powder and processing parameters.

\begin{tabular}{ccccc}
\hline $\begin{array}{c}\text { Sample } \\
\text { No. }\end{array}$ & $\begin{array}{c}\text { Particle size } \\
\text { in powder, } \mu \mathrm{m}\end{array}$ & $\begin{array}{c}\text { Plasma torch } \\
\text { power, } \mathrm{kW}\end{array}$ & $\begin{array}{c}\text { Total mass flow } \\
\text { of air, } \mathrm{g} \mathrm{s}^{-1}\end{array}$ & $\begin{array}{c}\text { Plasma jet } \\
\text { temperature, }{ }^{\circ} \mathrm{C}\end{array}$ \\
\hline 1 & $10-44$ & 40.8 & 5.35 & 3185 \\
2 & $10-44$ & 48 & 4.61 & 3107 \\
3 & $10-44$ & 48 & 5.29 & 3250 \\
4 & $10-44$ & 49.4 & 4.33 & 3123 \\
5 & $44-105$ & 49.4 & 4.46 & 3023 \\
6 & $44-105$ & 49.6 & 5.07 & 3212 \\
7 & $10-44$ & 54.2 & 5.24 & 3350 \\
\hline
\end{tabular}

of $\mathrm{Z} 1$ and $\mathrm{Z} 2$ powders, the particles are well melted and spheroidized after passing the plasma jet. As observed by scanning electron microscopy, a ball-like microstructure with relatively uniform size of powders is typical of all sprayed powders. This morphology promotes good flow ability of the powder during plasma spray deposition. Only the difference in the particle size of sprayed Z1 and Z2 powders was noticed. In the ini-

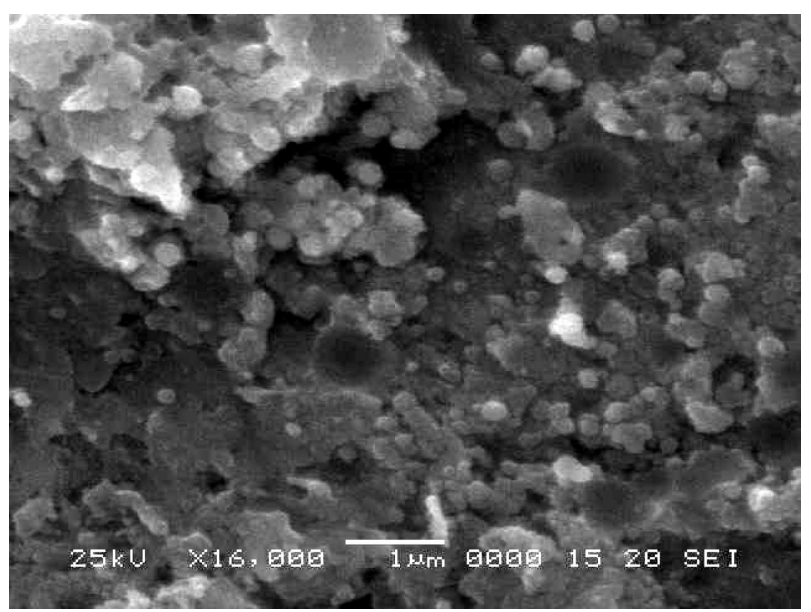

(a)

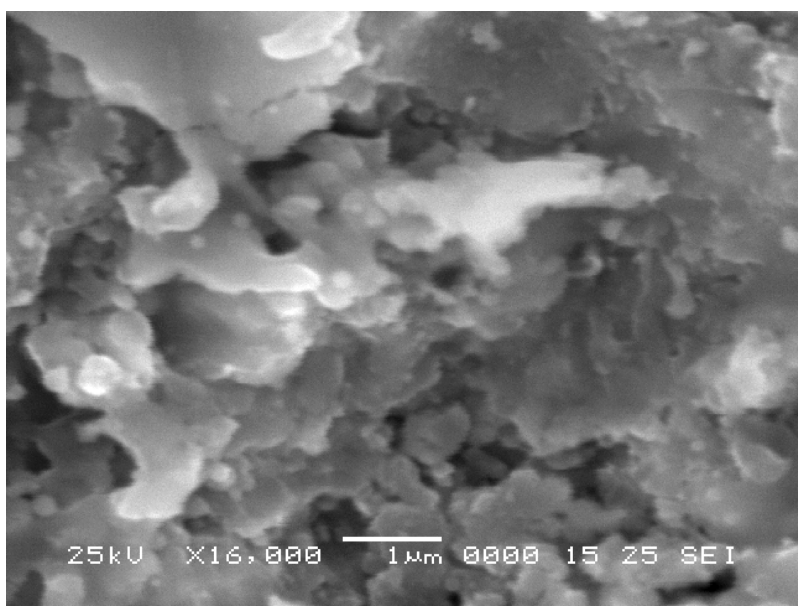

(c) tial powder Z1 particles are ball shaped with average size of granules about 20 micrometres. Plasma sprayed powders $\mathrm{Z} 2$ are characterized by sizes varying from 40 to 100 micrometres.

Typical SEM surface morphology of plasma sprayed YSZ coatings is shown in Fig. 2. These coatings were deposited from precursor $\mathrm{Z} 1$ at different values of amperage and, as a result, at different deposition

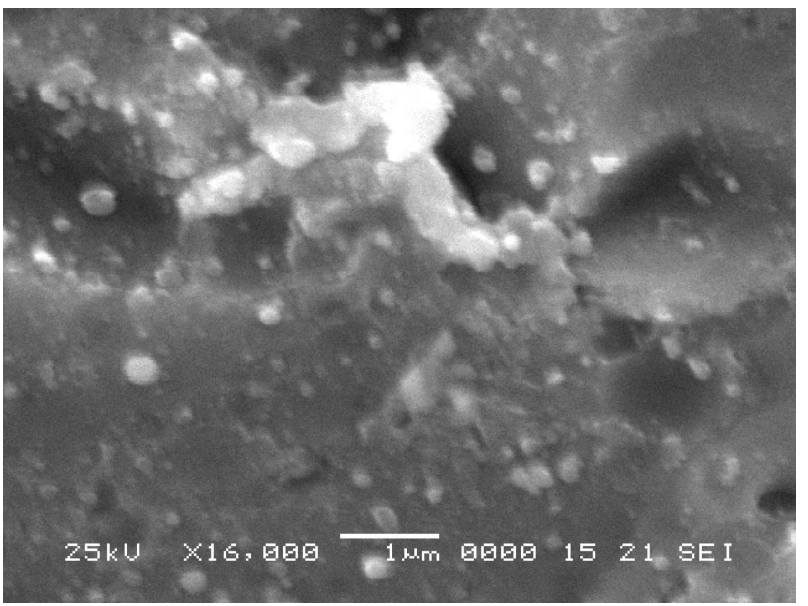

(b)

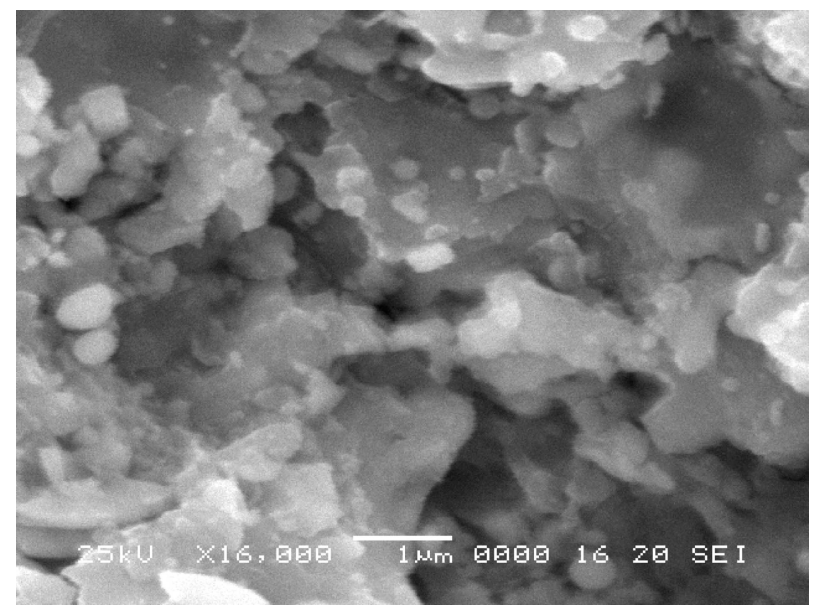

(d)

Fig. 2. SEM images of the top surface morphology of YSZ coatings plasma sprayed from Z1 powder at (a) $3107^{\circ} \mathrm{C}$ and (b) $3350{ }^{\circ} \mathrm{C}$ deposition temperature, and from $\mathrm{Z} 2$ powder at (c) $3023{ }^{\circ} \mathrm{C}$ and (d) $3212^{\circ} \mathrm{C}$ deposition temperature. 


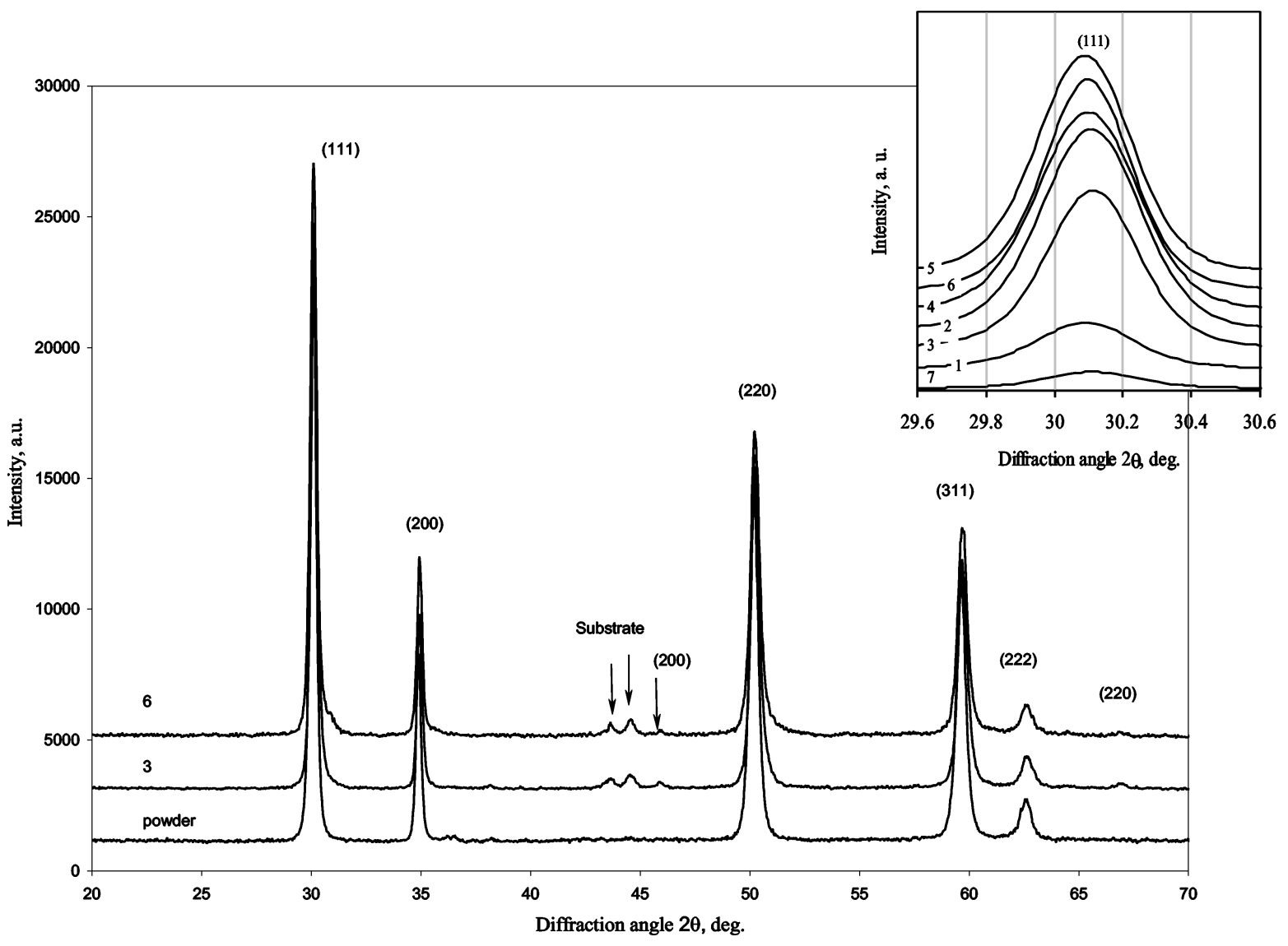

Fig. 3. The XRD patterns of initial powder of plasma sprayed zirconia samples.

temperature - (a) $3107^{\circ} \mathrm{C}$, (b) $3350{ }^{\circ} \mathrm{C}$, and from $\mathrm{Z} 2$ powder - at (c) $3023{ }^{\circ} \mathrm{C}$, (d) $3212^{\circ} \mathrm{C}$. The deposited coatings are characterized by homogeneous structure formed from fine and equal-sized grains. A uniform grain distribution is typical of all plasma sprayed YSZ. Comparison of the surface morphologies shows that YSZ coating deposited at higher temperature is characterized by finer grain size. The average grain size estimated from SEM analysis is about $150 \mathrm{~nm}$ for YSZ sprayed from $Z 1$ powder (Fig. 2(a, b)), while the grain size of material deposited from powder Z2 (Fig. 2(c, d)) is about $300 \mathrm{~nm}$. SEM investigations show that the YSZ coatings deposited at higher temperature are characterized by more dense and homogeneous structure due to better sintering at higher temperature. The higher density value of $5.20 \mathrm{~g} / \mathrm{cm}^{3}$ was determined for sample $\mathrm{N} 7$ deposited at $3350{ }^{\circ} \mathrm{C}$. The density of coating was measured by Archimedes method, which excludes an open porosity effect [12]. In comparison, the density of $8 \mathrm{YSZ}$ obtained by low pressure plasma spraying is $5.43-5.79 \mathrm{~g} / \mathrm{cm}^{3}$ [13]. The density of the as-sintered $8 \mathrm{YSZ}$ coating produced by electrophoretic deposition, measured by the Archimedes method, is $72 \%$ [12]. YSZ electrolytes were deposited using $8 \mathrm{~mol} \%$ YSZ powders by atmospheric plasma spraying (APS) with porosity of $8.2 \%$ [14]. 7-8\% YSZ coatings with density of 4.89$5.18 \mathrm{~g} / \mathrm{cm}^{3}$ were deposited with five different plasma spray systems by plasma spraying [15]. The density of thermal barrier coatings (8.7 YSZ), defined as coating mass (measurements of the plates' mass before and after deposition) per ceramic coating volume, obtained by electron beam physical vapour deposition, is declared to be $4.51 \mathrm{~g} / \mathrm{cm}^{3}$ [16].

The XRD analysis data of all studied coatings show (Fig. 3) that crystal structure of plasma deposited coatings is cubic zirconia (diffraction peaks attributed to the $111,200,220,311$, and 222 reflections of cubic zirconia were found) with different crystallite size depending on the processing parameters. By XRD, YSZ coatings are found to have a nanocrystalline cubic structure and a good preferential orientation at the 111 plane. As the deposition temperature increases, the size of the crystallite decreases (Fig. 4) but the crystal phase remains unchanged. It has been noticed that average crystallite size of plasma sprayed zirconia from large-sized precursor Z2 is higher than in the case of $\mathrm{Z1}$ powder.

The thickness of sprayed layer depends on spray duration and differs from $30 \mu \mathrm{m}$ for spray duration of 


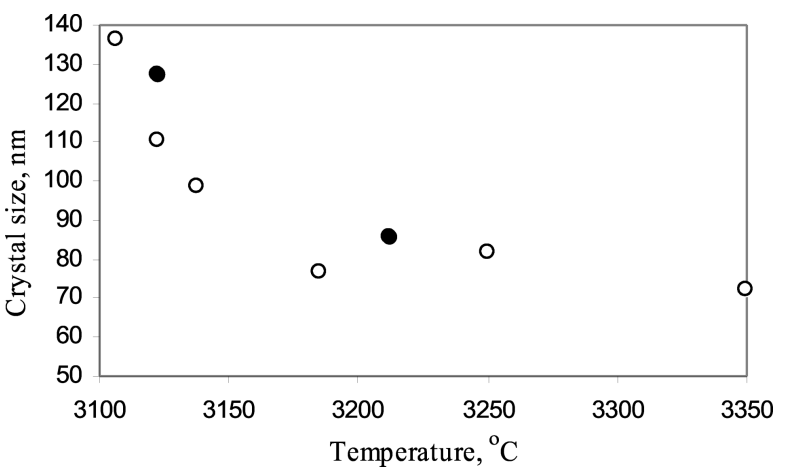

Fig. 4. Crystallite size of plasma sprayed YSZ coatings versus deposition temperature and powder used: white points for Z1, black points for Z2.

$30 \mathrm{~s}$ to $50 \mu \mathrm{m}$ for spray duration of $60 \mathrm{~s}$. It is determined that the optimal spray distance for both regimes is $70 \mathrm{~mm}$.

\section{Conclusions}

The paper describes a process for preparation of yttria stabilized zirconia (10-15 wt. \% $\left.\mathrm{Y}_{2} \mathrm{O}_{3}\right)$ coatings by plasma spray technique employing non-equilibrium plasma spray technology at atmospheric pressure. The effect of plasma deposition temperature on the microstructure of sprayed samples was investigated. It was found that this processing factor had a noticeable effect on the structure of plasma sprayed material. By the data of XRD analysis, all sprayed coatings are found to have a nanocrystalline cubic structure. The samples sprayed using coarse-grained powder feed (44-105 $\mu \mathrm{m})$ are characterized by larger crystallite size. The crystallite size has tendency to decrease with increasing the deposition temperature. From the data of SEM analysis the best temperature region for the deposition of YSZ coatings was found to be about $3200-3350{ }^{\circ} \mathrm{C}$ in the temperature region investigated.

\section{Acknowledgement}

Agency for International Science and Technology Development Programmes in Lithuania supported the work.

\section{References}

[1] O. Yamamoto, Solid oxide fuel cells: Fundamental aspects and prospects, Electrochim. Acta 45, 2423-2435, (2000).

[2] K.A. Khor, Z.L. Dong, and Y.W. Gu, Plasma sprayed functionally graded thermal barrier coatings, Mater. Lett. 38, 437-444 (1999).
[3] I.R. Gibson, G.P. Dransfield, and J.T.S. Irvine, Influence of yttria content upon electrical properties and susceptibility to ageing of yttria-stabilised zirconias, J. Eur. Ceram. Soc. 18, 661-667 (1998).

[4] W.E. Lee and W.M. Rainforth, Ceramic Microstructures: Property Control by Processing (Chapman \& Hall, London, 1994) p. 317.

[5] R. Vaßen, N. Czech, W. Malléner, W. Stamm, and D. Stöver, Influence of impurity content and porosity of plasma-sprayed yttria-stabilized zirconia layers on the sintering behaviour, Surf. Coatings Technol. 141, 135-140 (2001).

[6] G. Laukaitis, J. Dudonis, and D. Milcius, YSZ thin films deposited by e-beam technique, Thin Solid Films 515, 678-682 (2006).

[7] T. Bhatia, A. Ozturk, L. Xie, E.H. Jordan, B.M. Cetegen, M. Gell, X. Ma, and N.P. Padture, Mechanisms of ceramic coating deposition in solution-precursor plasma spray, J. Mater. Res. 17, 2363-2372 (2002).

[8] X.-J. Ning, C.-X. Li, C.-J. Li, and G.-J. Yang, Effect of powder structure on microstructure and electrical properties of plasma-sprayed $4.5 \mathrm{~mol} \%$ YSZ coating, Vacuum 80, 1261-1265 (2006).

[9] V. Valincius, P. Valatkevicius, and L.L. Pranevicius, Employment of electric arc for cover deposition, Electron. Electr. Eng. No. 1(19), 26-29 (1999).

[10] A. Ambrazevičius, Heat Transfer During Quenching of Gases (Vilnius, Mokslas, 1983) pp. 174-192 [in Russian].

[11] S. Krumm, An interactive Windows program for profile fitting and size/strain analysis, Mater. Sci. Forum 228231, 183-188 (1996).

[12] X.J. Lu and P. Xiao, Constrained sintering of $\mathrm{YSZ} / \mathrm{Al}_{2} \mathrm{O}_{3}$ composite coatings on metal substrates produced from electrophoretic deposition, J. Eur. Ceram. Soc. 27, 2613-2621 (2007).

[13] H. Hamatani, N. Shimoda, and S. Kitaguchi, Effect of the composition profile and density of LPPS sprayed functionally graded coating on the thermal shock resistance, Sci. Technol. Adv. Mater. 4, 197-203 (2003).

[14] C. Zhang, C.-J. Li, G. Zhang, X.-J. Ning, C.-X Li, H. Liao, and C. Coddet, Ionic conductivity and its temperature dependence of atmospheric plasma-sprayed yttria stabilized zirconia electrolyte, Mater. Sci. Eng. B 137, 24-30 (2007).

[15] H.E. Eaton and P. Zajchowski, High temperature particulate erosion of plasma sprayed YSZ versus selected powder characteristics and plasma torch designs, Surf. Coatings Technol. 120-121, 28-33 (1999).

[16] D.S. Almeida, C.R.M. Silva, M.C.A. Nono, and C.A.A. Cairo, EB-PVD TBCs of zirconia co-doped with yttria and niobia, a microstructural investigation, Surf. Coatings Technol. 200, 2827-2833 (2006). 


\title{
PLAZMOS SRAUTO TEMPERATŪROS IૃTAKA YSZ DANGŲ FORMAVIMUI IR STRUKTŪRAI
}

\author{
Ž. Kavaliauskas, K. Brinkienè, J. Čèsnienè, R. Kèželis
}

Lietuvos energetikos institutas, Kaunas, Lietuva

\section{Santrauka}

Tirti plazminių itriu stabilizuoto cirkonio oksido (YSZ) dangu formavimo ypatumai ir vertintos dangu struktūros charakteristikos. Cirkonio oksido dangos gautos plazminio purškimo būdu, taikant nepusiausviros oro plazmos technologiją. Purškimui naudoti 44$105 \mu \mathrm{m}$ dydžio YSZ (10-15 svorio $\% \mathrm{Y}_{2} \mathrm{O}_{3}$ ) milteliai. Dangos analizuotos rentgeno difrakcijos (XRD) ir skenuojančios elektroninès mikroskopijos (SEM) metodais. Pateikta gautų dangų struktūros, fazinès sudèties bei kristalitu dydžio priklausomybė nuo plaz- mos srauto temperatūros ir žaliavos miltelių smulkumo. Nustatyta, kad dangų struktūrą sudaro kubinès gardelès nanometrinio dydžio cirkonio oksido kristalitai, kurių dydis mažèja, didèjant plazmos srauto temperatūrai. Pastebètas nedidelis kristalitų dydžio padidèjimas naudojant stambesnès frakcijos YSZ miltelius. Nustatyta, kad didžiausią îtaką plazminiu būdu formuojamų YSZ dangų struktūrai turi purškimui naudojamų miltelių charakteristikos bei plazmos srauto temperatūra. Remiantis atliktais tyrimais, optimali plazmos srauto temperatūra YSZ dangoms formuoti yra $3200-3350{ }^{\circ} \mathrm{C}$. 